\title{
II. Observations on preserving specimens of plants
}

\author{
John Stackhouse Esq. F.L.S.
}

To cite this article: John Stackhouse Esq. F.L.S. (1800) II. Observations on preserving specimens of plants, Philosophical Magazine Series 1, 6:24, 302-304, DOI: $10.1080 / 14786440008677228$

To link to this article: http://dx.doi.org/10.1080/14786440008677228

册 Published online: 25 Jan 2010.

Submit your article to this journal 준

Џ Article views: 2

Q View related articles $₫$ 
II. Obfervations on preferving Specimens of Plants. $B y$ John Stackhouse, Efq. F.L.S.*

I

$\mathrm{N}$ profecuting my refearches with a view to complete the hiftory of the Britifh Fuci, I was defirous to difcover, if pof. fible, a method of preventing the olive-coloured, coriaceous fpecies from turning black in drying. For this purpofe I tried the experiment of immerfing them in a ftrong folution of alum. The refult of my experiment did not anfwer my expectation. They were prevented, indeed, from turning black, but they acquired a greenith hue. However, imagining this might arife from the mixture of aluminous with muriatic falts, and being of opinion that the properties of alum might be of great ufe in preferving land plants on feveral accounts, $I$ fet on foot a courfe of experiments, and am happy to fay, that the refult has been favourable to my expectations. After repeated trials, during which partial failures occurred, owing to the proportioning the degrees of ftrength of the folution, and the admiffion of light and air during the time of drying, I can fafely recommend to the public attention the procefs which follows, not doubting but that many improvements will fuggeft themfelves to thofe who poffefs a chemical knowledge of the various fubftances made: ufe of by dyers in fixing their colours.

Take a faturated folution of powdered alum in common water : immerfe carefully your fpecimen, flowers, leaves and ftalk in this liquor. During this immerfion, with a camel'shair brufh, fuch as varnifhers make ufe of, wet thoroughly a fheet of blotting-paper : difplay your fpecimen carefully on this paper, and prepare another heet in a fimilar manner to lay over your plant. Then give a fmart preffure to your plant, either with a botanical prefs, a napkin prefs, or weights of any kind applied to the fpecimen placed between fmooth boards, or books, obferving to lay about half a quire of paper below the fpecimen, and the fame quantity above, to take up the moifture. After a day or two, according to

* From the Trangabions of the Linnean Society, Vol. V. 
the fucculency of the plant, and when the aluminated paper appears perfectly dry, your fpecimen may be removed into frefh paper, and kept carefully under gentle preffure, with the edges of the paper folded over each other to prevent every poffible admiflion of light and air till its removal into the herbarium. For thofe who wifh to affix their fpecimens, (and it is fcarcely poffible to effect the prefervation of the delicate tints of the petals of many kinds without a ftrong adhefion to, and almoft incorporation with, the paper,) the time abore mentioned, that is, when the aluminated paper is thoroughly dry, is the proper time for proceeding with the operation. Have ready a pafte made with flour and water, with alum mixed in it, fuch as upholfterers ufe, ftrong gumwater, or ifinglafs-glue : apply either of thefe to the back of your fpecimen with a brufh; then fix it carefully on ftrong writing or drawing-paper, by laying your paper fmoothly on the fpecimen as it lies, preffing it gently with your hands and a cloth, and then turning over both together. When this is done, iron the plant with a box-heater in the manner recommended by Major Velley in Dr. Withering's Arrangement of Britifb Plants, v. r. p. 34, if you have the conveniences; if not, apply an immediate and fmart preffure, as before directed.

It is taken for granted that thofe who with to profit by thefe inftructions, are practifed in the ufual methods of preferving dry fpecimens, and that they are aware that particular care fhould be taken to pare off the back parts of thick woody ftalks, and of the globofe, fucculent heads of flowers, as well as of the buds of thofe intended to be pafted down, previous to their preffure. For the moft fatisfactory information on thefe particulars, the reader is referred to the Introduction to Dr. Withering's excellent work above mentioned. It is almoft needlefs to mention, that aluminated fpecimens will be eompletely guarded from the erofion of infects, as well as from the danger of being injured by damps; and therefore the procefs will be particularly valuable to thofe who vifit foreign countries.

As beauty and durability are of fo much confequence in the arrangement of an herbarium, and as plants cannot be preferved 
preferved any length of time in perfection even with the ufual apparatus of a vafculum, or tin-cafe, no botanical traveller fhould be without a fmall prefs, fuch as that defcribed in Dr. Withering's Arrangement, v. I. p. 3 r. It may be framed fo as to admit of a drawer for receiving the preferved fpecimens; either thin enough to lie under the feet in a poftchaife; or, as a feat for a third perfon is often defirable, if may be contrived to be as high as the feat of the carriage, with a correfponding cuthion on the top.

\section{II. A curfory View of fome of the late Difcoveries in Science.}

[Continued from Page 251.]

\section{ANATOMY OF ANIMALS.}

\section{C} UVIER has made many refearches refpecting the organifation of infects, and the manner in which nutrition takes place among them. "I I think I am the firft," fays he, "6 who has diftinguifhed worms into two grand families; the molufca, which have a heart, and a complete fy ftem of circulation; and zoophytes, which have neither. I have defcribed the heart, and the vafcular fyftem of the principal genera of the molufca; and I have proved that their venous veffels perform at the fame time the function of abforbing veffels." He then thows that infects have neither a heart nor veffels of circulation. Malpighi obferved in the filk-worm a large knotty veffel extending along the whole back, and he believed that this veffel performed the functions of the heare and aorta, and that the fame organifation exifted in all infects. This opinion was adopted by all naturalifts. Cuvier has carefully examined this veffel, as well as the whole organifation of infeets; but he obferved no movement of fluids, or circulation. Almolt the whole body of the infect is filled with tracheæ; from which he concludes that there is no real circulation in thefe animals, and that their nutrition is performed by immediate abforption, as is evident in polypes and other zoophytes, which are found immediately below infects in the fcale of organic perfection. 